by each agency as to what constitutes "quality" research.

In the year since the law was passed, the OMB has published draft guidelines that question whether peer review is, in itself, sufficient to guarantee quality. The OMB originally argued that it was not, citing "cases where flawed science has been published in respected journals".

In some cases, the OMB said, results must be "substantially reproducible" to pass muster. That raised eyebrows in some quarters, such as the National Academy of Sciences, whose president Bruce Alberts wrote in a public comment that reproducibility sets a "new and unreasonable standard" for disseminating scientific information.

The OMB backed off, but not entirely: "It is not OMB's intent that each agency must reproduce each analytic result before it is disseminated," the agency said in its final guidelines last month. But the data and methods used should be transparent enough for someone else to reproduce them.

Researchers fear that the law will be used unscrupulously by opponents of regulation to challenge findings, in disciplines such as climate or ecology, that may be difficult to replicate independently, as in cases where the opportunity to collect fresh data has passed.

Each agency is responsible for coming up with its own procedures for guaranteeing data quality and handling complaints. Jim Tozzi, a Washington-based regulatory consultant and CRE adviser, who signed the letter requesting the withdrawal of the National Climate Assessment, thinks the burden of proof will be on challengers.

"You have to have real data" to make a challenge, Tozzi says. But he predicts that if petitioners are not satisfied by an agency's response, disputes will end up in the courts.

Most federal agencies are still feeling their way to understanding the full implications of the law, according to Tozzi and others. The Environmental Protection Agency declined to comment on how it would draft its policies, and the White House science office, which received the CRE's complaint about the National Climate Assessment, says it is referring the matter to White House lawyers.

But at the Environmental Protection Agency and elsewhere, the level of concern is rising as the May deadline nears. The agency is inviting public comments online on the subject this week, when the National Academy of Sciences will also hold the first of a series of workshops on the law's implications.

www.whitehouse.gov/omb/fedreg/

reproducible.htm

\title{
Evolution critics seek role for unseen hand in education
}

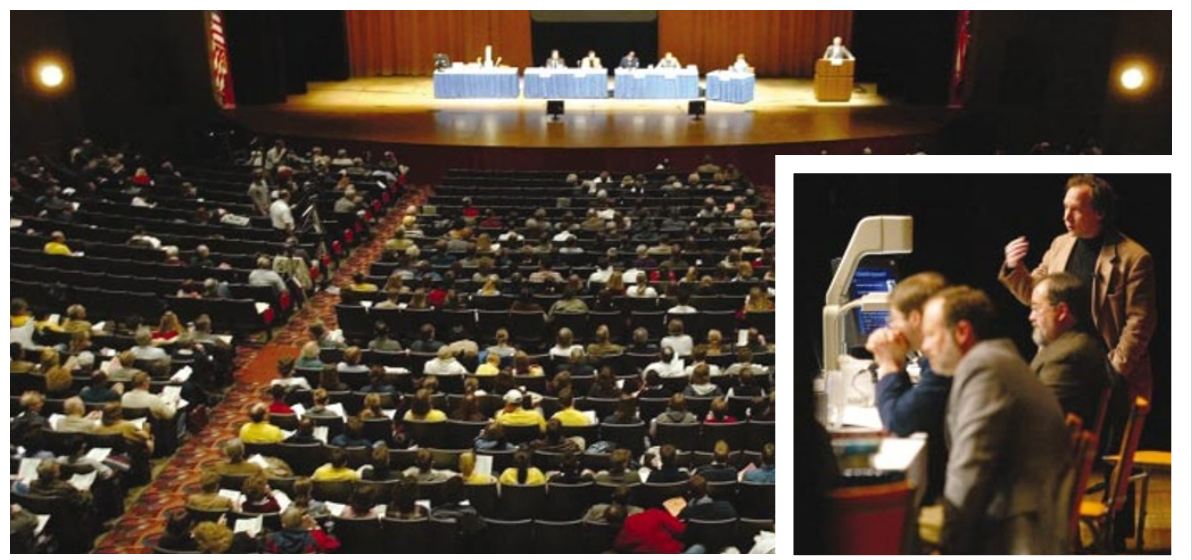

Creative thought: advocates and critics of 'intelligent design' cross swords in Columbus, Ohio.

Trisha Gura, Cleveland

The great debate on teaching evolution and creationism in American schools is back this time with an added twist.

The Ohio State Board of Education is being pressed to instruct teachers in the mid-western state to include 'intelligent design' in their biology lessons, as a possible alternative to Darwin's theory of evolution.

Proponents of 'intelligent design' concede that evolution takes place, but argue that its outcome is too complex to have occurred by chance and so must have been designed by some unseen hand. They told a rowdy public hearing of the board in Columbus on 11 March that including the topic in the school curriculum would help students to understand that scientific theories are always open to challenge.

But many scientists regard intelligent design' as pseudoscience, and say that it is being used as a Trojan Horse to introduce the teaching of creationism into schools.

On the other side of the Atlantic, meanwhile, scientists were protesting because of reports that Emmanuel College in Gateshead - a Christian-run technical college near Newcastle upon Tyne - is indoctrinating its students with creationist ideas. Richard Dawkins, an evolutionary biologist at the University of Oxford, accused the college of teaching "ludicrous falsehoods" and called on the government's education department to investigate further.

In the United States, school curricula are controlled at the state level, and Ohio's education board is revising its standards in response to instructions from Bob Taft, its Republican governor. But at least three members of the 19-person board have taken exception to a draft of the standards, produced in consultation with scientists, because it fails to acknowledge 'intelligent design' as a rival theory to that of evolution.
In response to these concerns, a subcommittee of the board invited two advocates of 'intelligent design' - Stephen Meyer and Jonathan Wells, both fellows of the Discovery Institute, a conservative think tank based in Seattle, Washington - to debate the topic with two of its critics, theoretical physicist Lawrence Krauss of Case Western Reserve University in Cleveland and cell biologist Kenneth Miller of Brown University in Providence, Rhode Island.

Around 1,500 people attended the sometimes-heated debate, in which Wells and Meyer characterized Darwin's theory as being under fire from within the scientific community. Wells waved a list of what he described as 40 peer-reviewed papers criticizing darwinism, and Meyer asked the board to "just permit teachers to teach the evolution controversy".

Krauss said that there was no such controversy. " 'Intelligent design' is an idea," he said. "It is not science, because it does not appear in any peer-reviewed literature." Miller and Krauss both dismissed 'intelligent design' as "creationism dressed up as science".

A subcommittee of the board is due to present standards for science, and other subjects under review, to the full board by September. The board is expected to implement the standards in December - just after elections for six of the board members.

Some observers of Ohio politics say that - with the tacit backing of Taft — the state might implement standards that will open the door to the teaching of 'intelligent design'. Biologists worry that such a move could force the topic into biology textbooks - and open the way for change in Texas, which will discuss its standards next year. "Ohio is just a skirmish," says Miller, a co-author of five biology textbooks. "But it is a rehearsal for what will happen later." 